\title{
Public Funds Management in Nigeria: The Praxis and Prognosis of Treasury Single Account Policy (2015-2019)
}

\author{
Ogwola Idoko Robert \\ Department of Public Administration, Federal University, Gashua, Nigeria
}

\section{Email address:}

Ogwola68@gmail.com

\section{To cite this article:}

Ogwola Idoko Robert. Public Funds Management in Nigeria: The Praxis and Prognosis of Treasury Single Account Policy (2015-2019). American Journal of Management Science and Engineering. Vol. 6, No. 1, 2021, pp. 26-33. doi: 10.11648/j.ajmse.20210601.14

Received: September 21, 2019; Accepted: October 22, 2019; Published: March 13, 2021

\begin{abstract}
The purpose of this paper was to evaluate the impact of implementation of treasury single account (TSA) policy on the economy of Nigeria between 2015 and 2019. Prior to the implementation of the TSA, multiple government's bank accounts held by its numerous ministries, departments and agencies (MDAs), especially those domiciled at commercial banks were believed to be conduit pipes through which public funds were drained. The argument which analysts had so far canvassed, and which seems to enjoy broad consensus, is that the introduction and implementation of the TSA (as obtainable in other economies such as Britain, US, Australia, Sweden, Cambodia, India, Indonesia, Central African Republic and Guinea Bissau among others) was capable of eradicating or minimising public funds wastage and diversion. Some further opined that TSA has the potential to address government borrowing and maximise the opportunity cost of cash resources. This paper therefore, makes an attempt to evaluate the implementation strategy of TSA and what impacts it has wielded on the economy of Nigeria. This paper also examined whether or not TSA is a potent tool for fostering good governance, transparency and accountability in the management of public funds. The method of research employed was secondary data analysis. The findings showed that the application of TSA in Nigeria was the desire to eliminate financial and economic corruptions characterising the public service in Nigeria, and as a consequence fosters transparency and accountability in the sector. Also it was found that there are some challenges involved in the implementation of the TSA in the country, however, a number of solutions were proposed which include: Using the TSA as both fiscal and monetary policy tools to stimulate growth and development in the nation's economy, produces and publish statement of accounts of the MDAs at periodic interval for the sake of real transparency, and the need to build synergy amongst the agencies responsible for national data generation and dissemination.
\end{abstract}

Keywords: Reinvent, Treasury, Single Account, Policy, Transparency, Accountability, Financial Management, Praxis and Prognosis

\section{Introduction}

An important aspect of government financial administration is the fiscal and monetary policy management dimensions. In every economy the world over, one of the objectives of government financial administration is the facilitation of efficiency and effectiveness in the use of public funds. The aim is to ensure that government scarce financial resources are optimally utilised such that the welfare of the citizenry is catered for, and their living conditions are enhanced in line with international standards. In order to tame the tide of financial recklessness and waste often occasioned by financial impropriety- which is partly encouraged by multiple accounts held by ministries, department and agencies (MDAs) - the Nigerian federal government therefore tinkered with the idea of Treasury Single Account (TSA) as a more effective policy option capable of retaining enough cash for public expenditure and investment purposes. The government also sees the policy as a means of checking financial profligacy pervasive in the public sector; or as a device for blocking the leakages in the finances of the government.

TSA is a unified systems of government bank accounts, or a set of linked accounts, that gives a consolidated view of government cash resources, government receipts and payments [1]. TSA is maintained based on the principle of 
unity of cash and unity of treasury. With this unison in focus, government receipts and payments are easily monitored in a way that transparency and accountability could be guaranteed. It is imperative to assert that one of the essences of this unison of treasury is to foster transparency, control and supervision over public funds which ideally should be held in public trust. However, the primary aim of TSA is to facilitate effective check over government cash balances [1]. Besides the above purpose, TSA is also designed to accomplish the following objectives.

Allows complete and timely information on government cash resources; improves appropriation control; improves operational control during budget execution; enables efficient cash management; reduces bank fees and transaction costs; facilitates efficient payment mechanisms; improves bank reconciliation and quality of fiscal data; lowers liquidity reserve needs; enthrone centralised, transparent and accountable revenue management; promote efficient management of domestic borrowing at minimal cost; allow optimal investment of idle cash; block loopholes in revenue management; and establish an efficient disbursement and collection mechanism for Government funds. [2]

It can be rationalised from the above that the reason for the choice of total implementation of the TSA by Muhammadu Buhari's government in in 2015 was therefore predicated on the believe that the policy would yield good governance, transparency and accountability with respect to the use of funds in Nigeria's public sector and in accordance with the aspirations of most Nigerians. The submissions of most Nigerian scholars and analysts, if not all of them, is that economic and financial corruption are the chief bane to Nigeria's development and prosperity [3-6].

At this juncture it is important to examine very briefly, the background to the introduction of TSA in Nigeria. The idea of TSA was mooted under the Presidency of Olusegun Obasanjo in 2004, but it was under Goodluck Jonathan's administration in 2012 that serious attention was paid to this policy option. Detail implementation of the policy did not occur until President Buhari became Nigeria's President in 2015. Although the constitution of the Federal Republic of Nigeria, 1999, as amended, and in section 80 (1), had since laid the foundation for a consolidated revenue account. The section avers:

All revenues, or other monies raised or received by the Federation (not being revenues or other monies payable under this said constitution or any Act of the National Assembly into any other public fund of the federation established for a specific purpose) shall be paid into and from one Consolidated Revenue Fund of the Federation. [7]

But the contrary was in practice until series of concerted efforts led to full-scale implementation of the TSA in 2015. Prior to the implementation of the policy in 2015, government officials in charge of public funds in the different Ministries, Departments and Agencies (MDAs) had maintained multiple accounts in different commercial banks. This development, according to analysts, paved the way for illicit pecuniary behaviour among public officials, which then resulted in unhealthy drain of the public treasury [8-9].

\section{Statement of the Problem}

It has been strongly argued that TSA is a powerful instrument or measure for checkmating illicit financial or pecuniary practices among public officials entrusted with public funds. This has been canvassed in different fora. This development therefore, made several countries to adopt the TSA: Australia, Brazil, Colombia, France, United States, Peru, Sweden, New Zealand, Russian Federation, and Georgia among others [1].

Although TSA is considered by several countries as the prettiest bride in town, however its detail implementation in Nigeria did not occur until about five years ago (i.e. 2015). Since the adoption of TSA Nigerians are yet to see the full benefits trickled down to them as obtainable in other countries. Without prejudice, there are claims that suggests that Nigeria has made some level of progress, albeit slowly than expected. For instance in 2012, former Nigerian President, Goodluck Ebele Jonathan averred that the minimal experimentation of the TSA under his watch as President showed that it had not only curtailed fiscal deficit regime but also improved the predictability of public expenditures [1011]. Additionally, it was reported that as at the last 22 Months of implementation, TSA was able to engender transparency and accountability, hence the federal government was able to keep tabs on its income henceforth [12]. Though, these are claims not backed up with statistics (figures). They however reflect to some discerning minds the possible benefits that will accrue from adopting the TSA. This study will therefore fill the perceived gap in the literature by employing secondary data/statistics to determine whether or not TSA actually promoted accountability and Transparency in the management of public funds within the period under review.

\section{Objectives of the Study}

The main objective of this study is to examine whether or not TSA, as a financial policy option, promotes accountability and transparency in the management of public funds. However, the more specific objectives of this study include:

i. To evaluate the contribution of TSA to transparency and accountability in public funds management in Nigeria

ii. To examine the impediments to TSA implementation in Nigeria

iii. To propose measures for enhancing implementation of TSA in Nigeria

\section{Literature Review}

In the context of our discussion, we have chosen to examine the following literature as they relate to the issues we have raised in our research questions. 


\subsection{Review of Contending Issues Surrounding the TSA}

In order to achieve effectiveness and efficiency in the management of public finance, the principles of integration, accountability and transparency are considered vital tools. In view of this believe, some nations, including Nigeria, which desired to promote good governance, accountability and transparency in public financial management (PFM) have resorted to the use of treasury single account (TSA) due to its ability to foster effective control and monitoring over the collection, custody and use of public funds. Highlighting the benefits of TSA, an IMF working paper explored the raison'de tre and supposed benefits of TSA to include the following:

A government lacking effective control over its cash resources can pay for its institutional deficiencies in multiple ways. First, idle cash balances in bank accounts often fail to earn market-related remuneration. Second, the government, being unaware of these resources, incurs unnecessary borrowing costs on raising funds to cover a perceived cash shortage. Third, idle government cash balances in the commercial banking sector are not idle for the banks themselves, and can be used to extend credit. Draining this extra liquidity through open market operations also imposes costs on the central bank. Establishing a unified structure of government bank accounts via a treasury single account (TSA) will solve these problems, improving cash management and control. [1]

Prior to 2015, when full implementation of TSA commenced it was widely acknowledged that the federal government of Nigeria lacked effective control over its cash resources. The MDAs were said to have maintained multiple accounts which aided unscrupulous financial practices on the part of public officials. For instance, it was reported that the Nigerian Communications Commission (NCC) had fraudulent produced two versions of audit report (one with lower figures sent to the Fiscal Responsibility Commission (FRC) and another with higher figures sent to the Office of the Auditor General of the Federation) probably with the intension to cover up some sharp financial activities [11]. The lists are quite numerous to mention all here.

It was against the above background that TSA was conceived in Nigeria. The ultimate aim was to ensure fiscal responsibility and efficiency. TSA therefore was intended to block all forms of financial leakages that hindered the growth and development of the nation. It was reasoned that TSA could equally be useful for national economic planning, swift and detail budget implementation; minimises leakages and other irregularities in the MDAs, aid data collection, analysis and timely aggregation of federal public funds among others [8]. However, as contained in the operational guidelines issued by the CBN in 2016, TSA was believed to:

Enthrone centralised, transparent and accountable revenue management; Facilitate effective cash management; Ensure cash availability; Promote efficient management of domestic borrowing at minimal cost; Allow optimal investment of idle cash; Block loopholes in revenue management; Establish an efficient disbursement and collection mechanism for Government funds; Improve liquidity reserve; and Eliminate operational inefficiency and costs associated with maintaining multiple accounts across multiple financial institutions. [2, 1]

The above objectives became necessary in view of the fact that government financial management system prior to implementation of the TSA was riddled with all sorts of financial impropriety which had denied the nation of several billions of US dollars in public revenue. For example, in mid-2015 it was reported that MDAs operated as many as 17, 000 accounts with the commercial banks [12]. These accounts cost the governments about N14.7 billion monthly in accounts management fees charged by the banks. Yet the national treasury was reported to have considerably slimed down in revenue. Further to the implementation of the TSA, the MDAs retained their individual accounts hitherto with the commercial banks called the Zero Balance Accounts (ZBAs), but daily funding of their disbursements were to be made through the main account, which is domiciled at the Central Bank, just as their closing balances at the end of each day's transactions are transferred to the TSA at the CBN. [11]

\subsection{Review of Contending Issues in Public Financial Management}

The idea of public sector financial efficiency has been at the front burner of macro-economic debates the world over, at least for nearly a century. It is commonly accepted that government is a product of social contract (JeanJacques Rousseau, 1712-1778). Consequently, public funds are held by government acting in the capacity of a trustee. Therefore, it is expected of the government to render account to the citizens, who elect that the state should govern on its behalf.

The importance of PFM to an economy cannot be overemphasised. Consider the extract below:

A strong PFM system is an essential aspect of the institutional framework for an effective state. Effective delivery of public services is closely associated with poverty reduction and economic growth, and countries with strong, transparent, accountable PFM systems tend to deliver services more effectively and equitably and regulate markets more efficiently and fairly. In this sense, good PFM is a necessary, if not sufficient, condition for most development outcomes. A key element of statehood is the ability to tax fairly and efficiently and to spend responsibly. These are fundamental characteristics of 'inclusive' state institutions, which generate trust, promote innovative energies and allow societies to flourish. See Acemoglu \& Robinso 'Why Nations Fail' and Dani Rodrik, 'In Search of Prosperity', both cited in Lawson. [13]

To gain the trust of the citizens, it is therefore necessary to promote transparency in the manner in which public resources are utilised for the well-being of the citizens. In to maximise public good and functions effectively, PFM is 
expected to fulfil the objectives below:

The maintenance of aggregate fiscal discipline is the first objective of a PFM system: it should ensure that aggregate levels of tax collection and public spending are consistent with targets for the fiscal deficit, and do not generate unsustainable levels of public borrowing. Secondly, a PFM system should ensure that public resources are allocated to agreed strategic priorities - in other words, that allocative efficiency is achieved. Thirdly, the PFM system should ensure that operational efficiency is achieved, in the sense of achieving maximum value for money in the delivery of services. Finally, the PFM system should follow due process and should be seen to do so, by being transparent, with information publicly accessible, and by applying democratic checks and balances to ensure accountability. [13]

\subsection{Theoretical Framework}

For the purpose of validating the questions we have raised, and based on the understanding that an ideal research work aims to either formulate new theory or validate an existing theory, we have decided to root our analysis on the theories of Pareto efficiency and the social contract.

\subsection{Pareto Efficiency Theory}

The theory of economic efficiency has its basis in the work of an Italian Scholar, Vilfredo Federico Damaso Pareto (1848 - 1923). As Pareto puts it, "a given economic arrangement is efficient if there can be no rearrangement which will leave someone else better off without worsening the position of the other" [14]. Economic efficiency therefore involves transparent and equitable use of public funds in order to promote common good. This theory is applicable to our study in the sense that it helps us to appreciate the benefit of economic efficiency in the way in which public funds are applied. It emphasises equity, justice and equanimity in the distribution of the commonwealth. Today in our nation, we could see some high level of economic inefficiency and disequilibrium, inequity and mismanagement of public funds being reported:

Governors and managers of government establishments in Nigeria proved reckless and inconsiderate managers of state resources. For example, it was claimed that the former Governor of Plateau State, Jonah Jang started a $\$ 15$ billion naira Government House project which his administration could not complete nor account for adequately before he left the office. Godswill Akpabio, former governor of Akwa-Ibom State, and later Senator, was said to have used state resources for the purchase of a state-of-the-art private jet to the tune of $\$ 45$ million. Chibuike Amaechi, former Governor of Rivers State also bought a Bombadier Global 5000 jet with number N565RS at the cost of $\$ 50$ million, the former Governor of Taraba (now late) Danbaba Suntai and his Osun state counterpart, Raulf Aregbesola were also said to have bought jets with public funds which they converted into their personal properties; and Gabriel Suswam, former Governor of Benue State was claimed to have bought SUVs utility vehicles worth several Millions of naira with state funds and donated same to the incoming Governor, Samuel Ortom at the twilight of his exit from government house [15-16].

The above extract further demonstrates the level of recklessness or financial impropriety characterising the manner in which public funds are misapplied by public officials entrusted with the mandate to make judicious use of the funds. This development partly necessitated the introduction of the TSA by the Nigerian government. As it were, we could say that prior to the adoption of TSA in Nigeria, public financial administration was fraught with inefficiency.

\subsection{The Social Contract Theory}

The idea of social contract enjoys much fame in the work of Jean-Jacques Rousseau (1712-1778). Although Aristotle and Thomas Hobbes had developed treatises on the subject long before Rousseau. However, his work on 'Social Contract' remains relevant and has gained wider application in several disciplines. The central idea in Rousseau's work focuses on the need for the governing authority to derive its powers through the consent of the people [17]. Social contract expresses the nature of relationship between the individual and society and its government.

The social contract assumed that the individual is the custodian of societal rights but that it voluntarily gave up some of these rights for the state to manage them for the common good. In return, the state is obligated to provide certain rights in the form of services or goods for the welfare of the individuals. Some of these rights include the rights to seek his consent about decisions that affect him, rights to demand accountability about how the state or government has appropriated and utilise the commonwealth amongst others.

As the above matrix shows, various parties or stakeholders are involved in the social contract. The individuals, groups, society and government are some of these stakeholders as far the social contract is concerned. The impression is that each stakeholder is willfully drawn into the contract whose terms are binding on the parties involved. However the fundamental principle is that every party to the contract is responsible in some way to the other and vice-visa.

In relation to our discourse, the social contract is applicable in the sense that it imbued the idea that governance is or they polity is a contract between the governor and the governed. In this form of social relationship, accountability and transparency are core factors or variables. The TSA therefore was conceived with the objective of promoting accountability and transparency in the management of public resources. It is about government being accountable to the people in the aspect of the management of the commonwealth. 


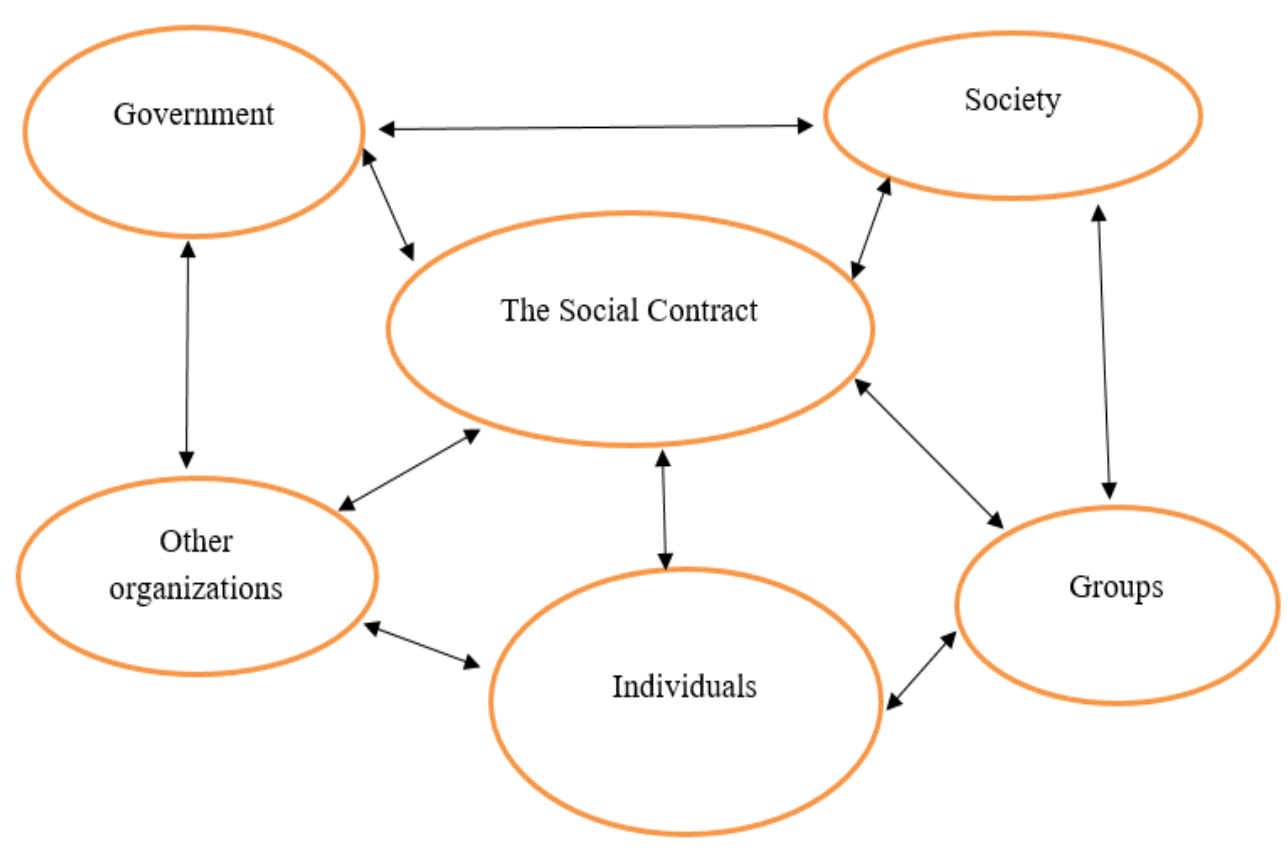

Figure 1. The social contract matrix.

Source: Adapted from Crowther, D. \& Seifi, S., Corporate governance and international business [18]. Retrieved from www.book.boon.com and modified by the Author.

\section{Methods of the Study}

On the design of this study, secondary data analysis was utilised. The choice of this design is informed by the understanding that since there was not enough funds for the researcher to conduct an extensive survey it was, in the alternative, wise to untilise data already collected by government agencies and other researchers who in our thinking had more funds to conduct a better survey.

On this note, our sources of data was basically secondary. Information or data were therefore sourced from reports and other publications of the government concerning TSA. Also empirical literature on the subjects of TSA activity in Nigeria were utilised. Journals, Newspapers and Magazines reports which carried relevant news items on the subject matter were harnessed. Last but not the least are publications and reports of the IGOs NGOs, especially those of IMF and others were examined.

A non-probability sampling, that is purposive sampling design, was applied in the collection of the secondary data for the purpose of our analysis. On the method of data analysis, the qualitative approach was employed. Secondary data collected were analysed by means of thematic presentation in texts or narrations; also pictorial analysis was done where necessary.

\section{Conceptual Explication}

As applicable in the context of our analysis, we have decided therefore to explain the following concepts:

TSA: This is an acronym used to refer to "treasury single account". It denotes a consolidated structure of government bank account or a set of linked bank accounts into which all payments and receipts are made by the ministries, departments and agencies of government. [2]

Accountability: This means to be answerable or responsible for an action, especially as it concerns the use of public trust or mandate. This is imperative because organisation or the individual representing it must act in recognition of wider societal interest, and not only the interest of the organisation owners alone. [18]

Transparency: This connotes the rights of the individuals or citizens, who are to be affected by decisions or their enforcement, to freely and directly have access to information without infringing on the rights of organisation to the proprietary of business information [18]. Transparency therefore means openness of public transactions to public scrutiny.

Public Financial Management (PFM): Embodies 'the set of laws, rules, systems and processes employ by sovereign states, or sub-national governments to mobilise revenue, allocate public funds, undertake public spending, account for funds and audit results'. [13]

Public Policy: Simply put, a policy is governmental course of action undertaken to address specific problem of concern within the lager society and has attracted the attention of government.

Public Funds: This refers to all revenue receipts and expenditures of government.

Praxis: This refers to the way a system, policy, idea or theory is used or applied by individuals or organisations in the society.

Prognosis: In the context of this study, this term is used to refer to the way organisation or individual forecasts how situation or system is likely to develop in the future. 


\subsection{Discussion}

It has been mentioned that TSA is not a Nigerian innovation. Several countries have adopted it before Nigeria contemplated its implementation at the national level. As we earlier commented, the choice of this policy option was based on the understanding that the public sector in Nigeria is infested with financial hemorrhage. Financial accountability and transparency are thrown to the dogs. Proliferations of bank accounts, especially those maintained in the commercial banks have made public funds diversion easier. Billions of dollars of public funds are drained on regular basis, thereby creating the room for funds shortage and stampeding the flow of government businesses and welfare programmes. It is this precarious background which gave rise to the need for the TSA in Nigeria.

\subsection{The Drivers of TSA}

The TSA was introduced in Nigeria in 2012 under President Goodluck Jonathan's administration but there was no full-scale implementation until in 2015 when Mohammed Buhari assumed the mantle of leadership in May, 2015. From the discussion we have had, it is has been made obvious that TSA option came as an instrument for arresting the unscrupulous financial practice going on in the public domain.

However, it is important to note that certain factors have served as the incentives for the formulation of the TSA. First and most importantly is the reckless financial behaviour of the public officers, especially those who keep custody of government funds. Financial corruption remains a major albatross to our national development and needed an effective antidote [19]. TSA is considered an effective panacea to financial impropriety in Nigeria's public sector, hence its implementation is thought to eliminate the illicit financial flow in the sector.

The second driver is the undesirable costs that the government incurred as a result of borrowing from the commercial banks in spite of the fact that MDAs have lots of cash lying idle in these commercial banks. It makes no economic sense that government had to borrow when its agencies have so much cash starched idle in the commercial bank [12]. The idle cash which were hitherto lodged in secret accounts maintained by commercial banks could be plough back into productive use by the government or its MDAs. In this way, the temptation to divert the cash into some private use would have been averted. For instance, in mid-2015 MDAS operated as many as 17,000 accounts in the commercial banks; further to this, the accounts cost the government some estimated 14 Billion monthly in account management fees [12]. The desire to eliminate this uneconomical management of public accounts is another reason for the TSA.

Thirdly, the TSA is believed to foster accountability and transparency in the way public funds are managed. The TSA thus operates in such a way that public funds are maintained in a single but centralized treasury. In this way the leadership and people are able to keep close tabs on public funds. Consequently, the diversion of funds would be minimised. This concern is one of the motivations for the adoption of the TSA.

The Nigerian constitution in Sections 80 and 162 provided for a consolidated account for public revenue. Notwithstanding the provisions of the constitution, implementation remained a challenge as the MDAs maintained multiple accounts in different commercial banks prior to the consideration of the TSA. Part of the reasons why the TSA was considered for full implementation was also to fulfil constitutional requirement. Perhaps the makers of Nigeria's constitution having envisaged the implications a non-consolidated funds might have on the economy of the nation, hence they had legislated for its adoption in public financial management.

Another factor which aided the TSA policy is the advancement in computer and internet technology. Technological advancements played critical role in changing governments' banking operations in recent times. Transaction processing has improved remarkably, and electronic payment systems has made banking a lot easier; the availability of ebanking networks allows for a very effective banking services. Government cannot do less, but take advantage of this development in order to consolidate its hold on the public funds [1].

With the reasons given above it was obvious that the TSA would be practically accepted as the choicest alternative for mitigating the spate of illicit financial activities characterising the public service in Nigeria. This development would further enhance transparency and accountability in the management of state's resources.

\subsection{Challenges of TSA}

Although the TSA is considered as the best practice as it concerns public funds management, however it is adoption is still fraught with a lot of issues which challenge its efficacy in the context of Nigeria.

The first visible problem lay in the fact that commercial banking operations in Nigeria depends on much of the cash deposits maintained by the MDAs for effective operations. Thus the dismantling of these deposits meant that the commercial banks would loss estimated two trillions in cash deposits [19]. Obviously this development might put compelling pressures on the ability of these banks to operate optimally. It must be borne in the heart that Nigeria's private sector depends substantially on the public agencies to function optimally. Depriving them of this 'life jacket' meant that they would be operationally strangled. TSA takes away this life jacket by depriving the private businesses of their major source of liquidity or finance, which is the public sector. This might orchestrate the elimination of the businesses which are not financially buoyant.

The second challenge has to do with the difficulty the spending MDAs have to face in terms of their ability to have access to liquidity in order to meet daily operational expenses. This would put pressure on the daily operations of 
the MDAs as daily banking progress might be taunted. The centralised payment solution via the TSA comes with some bureaucratic bottleneck and red-tapism as illustrated in figure 2 below.

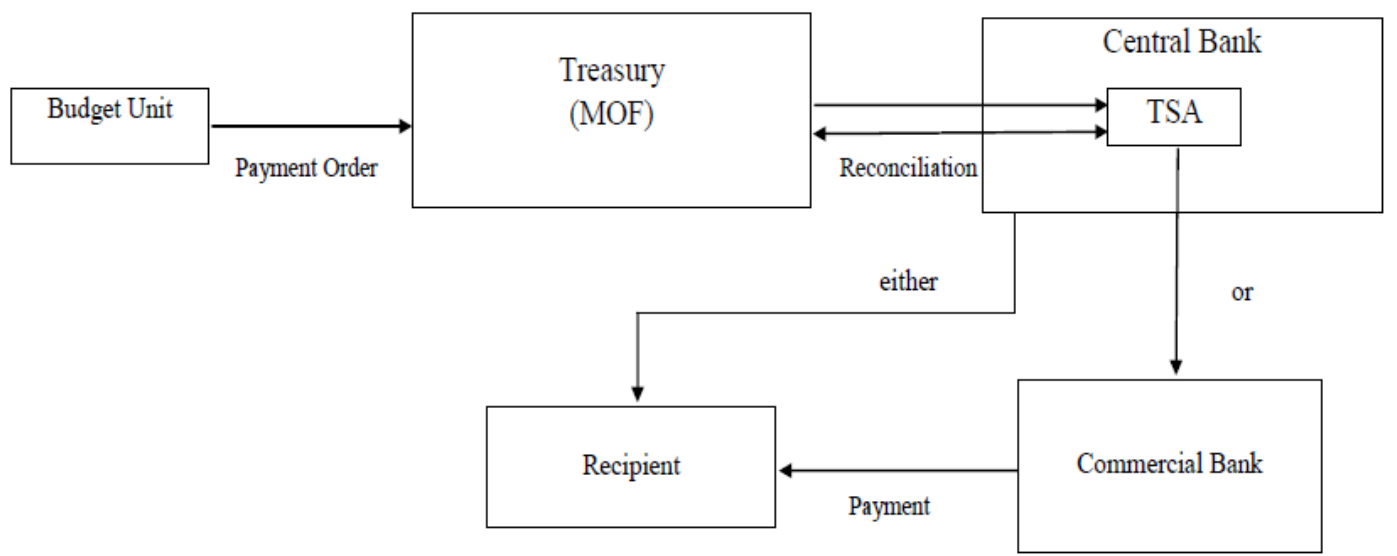

Source: adapted from: Sailendra, P. \& Israel, F., Treasury single account: Concept, design and implementation issues. IMF Working Paper [1]

Figure 2. Centralised TSA Structure.

The third is that, the money markets also faces it's on fair share of the bargain, as the squeeze in liquidity impacted negatively on the lending powers of the commercial banks. This has the potential to financially dehydrate small and medium term businesses in the country. Expectedly, several businesses went into limbo, and more others close operations due to dearth of loanable funds or credit facilities to augment available but limited private capital. This stifled investment opportunities and consequently occasioned the loss of jobs. On the whole, it is strongly argued that:

The implications of the TSA as a factor in the 2016 and 2017 recession in Nigeria included destructive macroeconomic vulnerability, exposure of the economy to risks and affront of economic nature, altered linkage between the financial markets and the economy, unprecedented capital outflow from the country, informal sector dollarization as against the naira, amongst hosts of other issues. [19]

\section{Conclusion}

The TSA was seen by Nigeria's policymakers as a child of necessity. This was because, after careful evaluation of other available alternatives, it was the option that is considered more effective enough to resolve the lingering financial crisis bedeviling the public sector. The MDAs which are the spending units of the government were considered to have chosen the path of dishonour by engaging in corrupt practices in flagrant violation of the constitution of Nigeria, 1999 (as amended). The law permits only the maintenance of a consolidated treasury account; but the MDAs were doing the opposite. Most if not all of them had maintained multiple accounts in commercial banks, which they used to divert public funds unnoticed.

To tame this unfortunate behaviour, TSA was adopted to among other things: unify government banking arrangement, which enables the Ministry of Finance or the treasury have oversight of government cash flows in and out of bank accounts; to consolidate government cash resources in order to facilitate effective budgeting and budget monitoring; and above all to enhance transparency and accountability in the management of public resources.

Despite the above objectives, the full-scale implementation of the TSA is believed to have some salient challenges which involves its ability to cripple the money markets by depriving it of state's funds and a number of other factors already discussed earlier. To surmount the perceived challenges the following recommendations are proffered as the prognosis for addressing the unintended consequences of the TSA on the economy of the country.

\section{Recommendation}

i. The TSA should not only be seen as efficient in transforming inputs but also as a responsive and innovative fiscal and monetary policy instruments that could foster growth and development of the Nigerian economy by stimulating the economy with injection of idle cash into the money markets.

ii. Secondly, if the real objective of TSA was to foster transparency in public funds management, then there should be a concerted effort to publish the statement of accounts of the TSA on regular basis (preferably, on quartile basis) so that the citizens and other stakeholders could ascertain the real financial position of the MDAs and the gains or losses incurred so far.

iii. Thirdly, the Central Bank of Nigeria and National Bureau of Statistics and the Budget office should maintain a synergy in data generation and dissemination in terms of the activities of the TSA. This will go a long way in shaping research into the operations of the TSA and allied studies.

\section{References}

[1] Sailendra, P. \& Israel, F. (2010). Treasury single account: Concept, design and implementation issues, IMF Working Paper. 
[2] CBN - Central Bank of Nigeria (2016). Guidelines for the operation of Treasury Single Account (TSA) by state governments in Nigeria, Abuja: Author; also see Sailendra, P. \& Israel, F. (2010). Treasury single account: Concept, design and implementation issues, IMF Working Paper.

[3] Ribadu, N. (2004). The role of EFCC in sanitising the Nigerian economic environment in a democratic setting. Being a paper presented at the Adamawa Economic Conference and Financial Exhibition, December 9-10, 2004. Retrieved from www.nigerianlawguru.com/articles/criminal $\% 201 \mathrm{law} \% 20$ and $\%$ 20procedure/ROLE\%20OF\%20EFCC.pdf

[4] Seteolu, D. (2004). The challenge of leadership and governance in Nigeria, in Odion-Akhaine, S. (2004) Governance: Nigeria and world, Lagos: Cencod.

[5] Raimi, L., Suara, I. B. \& Fadipe, A. O. (2013). Role of economic and financial crimes commission (EFCC) and independent corrupt practices \& other related offences commission (ICPC) at ensuring accountability and corporate governance in Nigeria, in Journal of Business Administration and Education, 3 (2), 105-122.

[6] Folarin, S. (2014). Corruption, politics and governance in Nigeria. Retrieved from https://www.eprints.covenantuniversity.edu.ng/3249/1/Folarin $\% 202$.pdf

[7] Federal Republic of Nigeria (1999). The 1999 constitution (As amended). Lagos: Federal Government Publishers.

[8] Okerekeoti, C. U. \& Okoye, E. I. (2017). Treasury single account (TSA) in Nigeria: A theoretical perspective. The 2017 international conference on African entrepreneurship and innovation for sustainable development (AEISD).

[9] GOMATAS (2017). Eight major effects of treasury single account on the economy of Nigeria (TSA). Retrieved from https://medium.com/@ggomtas/eight-major-effects-of- treasury-single-account-on-the-economy-of-nigeria-tsa$7064316 \mathrm{~d} 26 \mathrm{fb}$

[10] Yusuf, I. A. \& Chiejina, N. (2015, August $16^{\text {th }}$ ). Anti-graft war: One economy, one account. In the Sunday Nation, Pp. 9$10 \& 71$

[11] Eme, O. I., Chukwurah, D. C. \& Iheanacho, E. M. (2015). An analysis of pros and cons of treasury single account policy in Nigeria. In Arabian Journal of Business and Management Review (OMAN Chapter) 5 (4) pp. 21-36.

[12] Ejiofor, R. (2017, July $\left.29^{\text {th }}\right)$. TSA: Why government needs to advance FinTech agenda. Retrieved from www.vangauardngr.com/

[13] Lawson, A. (2015). Public financial management. GSDRC. Retrieved from www.gsdrc.org

[14] Musgrave, A. R. \& Musgrave, B. P. (2006). Public finance in theory and practice $\left(5^{\text {th }}\right.$ Ed,). New Dehli: Tata McGraw-Hill Co. Ltd.

[15] Salif, A. (2015, July 20). Bailout postpones the evil day, In Tell Magazine, Lagos: Tell Communications, pp. 16-19.

[16] Ogwola, I. R. \& Salifu, O. D. (2016). Internal Revenue Generation in Nigeria in an Era of Economic Recession: Contending Issues and Missing Policy Links. In The Certified National Accountant, 24 (4). Pp. 33-39.

[17] Behrens, L. \& Rosen, L. (1988). Themes and variations: The impact of great ideas. Scott, Foresman and Company.

[18] Crowther, D. \& Seifi, S. (2011). Corporate governance and international business. Retrieved from www.book.boon.com

[19] Amadasun, A. B. (2017). Stimulating the Nigeria economy in a period of economic recession through treasury single account: Issues in missing economic policy lessons. An editorial in the certified national accountant, 24 (4) pp. 3-6. 